pulmonar asociada a conducto arterioso permeable a una altitud de 2680 metros sobre el nivel del mar. Arch Cardiol Mex. 2012;82:290-6.

2. Estébañez-Muñoz M, Soto-Abánades $\mathrm{Cl}$, Ríos-Blanco JJ, et al. Updating our understanding of pulmonary disease associated with HIV infection. Arch Bronconeumol. 2012;48:126-32.

3. Sandoval Gutiérrez JL. Hipertensión arterial pulmonar asociada al virus de inmunodeficiencia humana. Un enfoque clínico. Revista Española de Hipertensión Pulmonar. 2013;3:22-9.

4. Mirrakhimov AE, Ali AM, Barbaryan A, et al. Human immunodeficiency virus and pulmonary arterial hypertension. ISRN Cardiol. 2013;2013:903454.
José Luis Sandoval-Gutiérrez

Centro de Investigación en Enfermedades Infecciosas, Instituto Nacional de Enfermedades Respiratorias, Ciudad de México, México

*Tlalpan 4502, Del. Tlalpan, CP. 14080. Ciudad de México, México. Teléfono: 54871700 ext 5226.

Correo electrónico: sandovalgutierrez@gmail.com

http://dx.doi.org/10.1016/j.acmx.2013.12.001

\section{Substrate-based strategies for paroxysmal refractory VT catheter ablation: Coming of age?}

\section{Técnicas basadas en el sustrato para la ablación con catéter de la TV paroxística refractaria: ¿están lo suficientemente maduras?}

\section{Dear Editor,}

Patients with ischemic and nonischemic cardiomyopathy are at increased risk of sudden death due to ventricular arrhythmias. Implantable cardioverter-defibrillators (ICD) have lowered this mortality rate; however, ICD shocks impact quality of life. ${ }^{1}$ Medical treatment with the combination of betablockers with amiodarone reduces ventricular tachycardia (VT) inducibility ${ }^{2}$ and ICD shocks, ${ }^{3}$ but longterm side effects are unfortunately relatively frequent. In patients with sustained paroxysmal refractory VT, catheter ablation has been proven to reduce VT recurrence by directly addressing the arrhythmogenic substrate, albeit at a procedure-dependent risk; nevertheless, ablation has no effect on mortality. ${ }^{4}$

Catheter mapping of recurrent VT relies on arrhythmia induction and identification of ablation targets (isthmuses and exit sites) by entrainment and activation criteria during ongoing VT. Ideally, it provides an endpoint to the procedure in the case of non-inducibility of VT. However, this approach is somewhat difficult due to some potential limitations: non-inducibility of VT, VT pleomorphism due to complex substrates, hemodynamic compromise. Therefore, these limitations have driven the development of substratebased mapping and new ablation strategies.

In patients with structural heart disease, ventricular scar represents the anatomical (and electrophysiological) basis for VT initiation and its maintenance. Abnormal local electrograms in sinus rhythm (SR) have been identified in border zones surrounding the scar. Surgical resection of subendocardial and/or epicardial reentry circuits was first attempted as an ablative method.

In the February 2013 issue of this Journal, Vergara et al. published a review of current substrate-based strategies for VT catheter ablation. ${ }^{5}$ They comprehensively describe several approaches to substrate ablation. The first two methods reported, conceptually derived from surgical ablation, employ linear ablation lines to cross, encircle or link the scar and anatomical barriers. Arenal et al. ${ }^{6}$ elegantly identified channels of delayed conduction through the scar zone through a step-wise reduction in voltage thresholds, targeting these areas with relatively few applications. However, the absence of a clear end point can limit its efficacy. The same technique was used by Berruezo et al. ${ }^{7}$ in a series of arrhythmogenic right ventricular dysplasia patients. Alternatively, Vergara et al. ${ }^{8}$ focused on complete mapping and ablation of late potentials (LPs), combined with pace-mapping in SR and, when possible, entrainment maneuvers. LPs ablation was associated with low VT recurrence rates and was a good predictor of arrhythmiafree survival. Thus, the authors postulated that "complete" LPs elimination is superior to non-inducibility of VT, given its ability to simultaneously address multiple circuits.

In spite of their promising results, several limitations remain. The population of these studies is heterogeneous as to VT induction and hemodynamic stability, thereby providing a possible bias. While the procedural endpoint has mostly been substrate-based, Soejima et al. ${ }^{9}$ found that non-identification of an isthmus was associated with recurrence. Also, different bipolar voltage cut-offs were used. Lastly, the ablation strategies have not been directly compared.

Despite these limitations, the current review by Vergara et al. suggests that substrate mapping and ablation strategies could be a valuable addition to the field of chronic recurrent VT catheter ablation, hopefully translating into a better clinical benefit for our patients.

\section{References}

1. Poole JE, Johnson GW, Hellkamp AS, Anderson J, Callans DJ, Raitt $\mathrm{MH}$, et al. Prognostic importance of defibrillator shocks in patients with heart failure. N Engl J Med. 2008;359:1009-17.

2. Tonet J, Frank R, Fontaine G, Grosgogeat Y. Efficacy and safety of low doses of beta-blocker agents combined with amiodarone in refractory ventricular tachycardia. PACE. 1988;11:1984-9.

3. Connolly SJ, Dorian P, Roberts RS, Gent M, Bailin S, Fain ES, et al. Comparison of beta-blockers, amiodarone plus beta-blockers, or sotalol for prevention of shocks from implantable cardioverter defibrillators: the OPTIC Study: a randomized trial. JAMA. 2006;295:165-71.

4. Mallidi J, Nadkarni GN, Berger RD, Calkins H, Nazarian S. Metaanalysis of catheter ablation as an adjunct to medical therapy for 
treatment of ventricular tachycardia in patients with structural heart disease. Heart Rhythm. 2011;8:503-10.

5. Vergara P, Roque C, Oloriz T, Mazzone P, Della Bella P. Substrate mapping strategies for successful ablation of ventricular tachycardia: a review. Arch Cardiol Mex. 2013;83: 104-11.

6. Arenal A, del Castillo S, Gonzalez-Torrecilla E, Atienza F, Ortiz M, Jimenez J, et al. Tachycardia-related channel in the scar tissue in patients with sustained monomorphic ventricular tachycardias: influence of the voltage scar definition. Circulation. 2004;10:2568-74.

7. Berruezo A, Fernández-Armenta J, Mont L, Zeljko H, Andreu D, Herczku C, et al. Combined endocardial and epicardial catheter ablation in arrhythmogenic right ventricular dysplasia incorporating scar dechanneling technique. Circ Arrhythm Electrophysiol. 2012;5:111-21.

8. Vergara P, Trevisi N, Ricco A, Petracca F, Baratto F, Cireddu $M$, et al. Late potentials abolition as an additional technique for reduction of arrhythmia recurrence in scar related ventricular tachycardia ablation. J Cardiovasc Electrophysiol. 2012;23:621-7.

9. Soejima K, Suzuki M, Maisel WH, Brunckhorst CB, Delacretaz E, Blier L, et al. Catheter ablation in patients with multiple and unstable ventricular tachycardias after myocardial infarction: short ablation lines guided by reentry circuit isthmuses and sinus rhythm mapping. Circulation. 2001;104:664-9.

Dorian Nitu, Xavier Waintraub, Joelci Tonet*

Cardiology Institute, Rhythmology Unit, Pitié-Salpêtrière Hospital, Paris, France

* Corresponding author.

E-mail address: joelci.tonet@psl.aphp.fr (J. Tonet).

http://dx.doi.org/10.1016/j.acmx.2013.11.002 